Sakr F, Akiki Z, Dabbous M, Salameh P, Akel M. The role of pharmacists in providing immunization to the general population: Are Lebanese pharmacists ready for this role? Pharmacy Practice 2021 Oct-Dec;19(4):2565.

Original Research

\title{
The role of pharmacists in providing immunization to the general population: Are Lebanese pharmacists ready for this role?
}

\author{
Fouad SAKR ID, Zeina AKIKI (D), Mariam DABBOUS (D), Pascale SALAMEH (iD, Marwan AKEL (iD) \\ Received (first version): 20-Sep-2021 Accepted: 11-Nov-2021 Published online: 13-Nov-2021
}

\begin{abstract}
Background: Vaccination rates remain suboptimal in multiple areas around the world in spite of evidence that immunization is one of the most effective interventions for precluding morbidity and mortality. Non-traditional vaccine providers are proposed to augment immunization coverage. Pharmacists can have multiple vital roles to educate, facilitate and immunize against vaccine-preventable diseases. Limited data are available around the expertise and practices of Lebanese pharmacists in providing immunization services. Objective: This study aimed to determine predictors that are associated with vaccine administration by pharmacists in Lebanon, and to assess experiences and practices in providing immunization. Methods: This is a cross-sectional study that included pharmacists from all over Lebanon. A web-based self-administered validated questionnaire was adapted with permission. A snowbal sampling technique was used to collect data through an electronic self-administered questionnaire between March and June 2021. The web-link to the survey was also shared by the Order of Pharmacists of Lebanon with all registered pharmacists to gather a sample from different districts all over Lebanon. Results: A total of 315 pharmacists were included. A significant positive association was found between completion of an immunization training program $(\mathrm{ORa}=2.085,[95 \% \mathrm{Cl} 1.006: 4.322], \mathrm{P}=0.048)$, full-time pharmacists (ORa $=2.504,[95 \% \mathrm{Cl} 1.156: 5.426], \mathrm{P}=0.02), 1$ to 4 years of practice experience $(\mathrm{ORa}$ $=3.855,[95 \% \mathrm{Cl} 1.849: 8.039], \mathrm{P}<0.0001)$, geographic area of practice (ORa $=3.201,[95 \% \mathrm{Cl} 1.242: 8.249], \mathrm{P}=0.016 ; \mathrm{ORa}=5.373,[95 \% \mathrm{Cl} 1.859: 15.530], \mathrm{P}$ $=0.002$ for Beirut and Mount Lebanon respectively), educating the public about immunization (ORa $=3.012,[95 \% \mathrm{Cl} 1.281: 7.083], \mathrm{P}=0.011)$; and vaccine administration. Conclusion: The study highlights the need for additional immunization training programs to pharmacists to expand their ability and role as immunizers. It also provides intuition for policy makers to upgrade legislation relating to pharmacy continuing education and immunization training in order to enable pharmacists to have a greater role in direct vaccination.
\end{abstract}

\section{Keywords}

Immunization; Vaccines; Pharmacists; Experiences; Practices

Fouad SAKR*. PharmD, MPH. Clinical Associate Professor. Lebanese International University, School of Pharmacy, Lebanon. Université Paris-Est Créteil, École Doctorale Sciences de la Vie et de la Santél, France. Institut Mondor de Recherche Biomédicale, France. fouad.sakr@liu.edu.lb Zeina AKIKI. PhD. Assistant Professor. Institut National de Santé Publique, Epidémiologie Clinique et Toxicologie Liban (INSPECT-LB), Lebanon. Lebanese University, Faculty of Public Health, Lebanon. zeinaakiki@hotmail.com Mariam DABBOUS. PharmD. Clinical Associate Professor. Lebanese International University, School of Pharmacy, Lebanon. mariam.dabbous@liu.edu.lb Pascale SALAMEH. PharmD, MPH, PhD, HDR. Professor. Institut National de Santé Publique, Epidémiologie Clinique et Toxicologie - Liban (INSPECT-LB), Lebanon. Lebanese University, Faculty of Pharmacy, Lebanon.University of Nicosia Medical School, Cyprus. pascalesalameh1@hotmail. com

Marwan AKEL. PharmD, MPH, PhD. Clinical Associate Professor. Lebanese International University, School of Pharmacy, Lebanon. Institut National de Santé Publique, Epidémiologie Clinique et Toxicologie - Liban (INSPECT-LB), Lebanon. International Pharmaceutical Federation (FIP). marwan.akel@liu.edu.lb

\section{INTRODUCTION}

Immunization is one of the most beneficial and efficient practices in contemporary medicine to prevent various infections and their detriments. ${ }^{1-3}$ The attainments of immunization through vaccination range from the universal elimination of smallpox to a significant reduction in Haemophilus influenzae type b invasive infections in the developed nations. ${ }^{4}$ In spite of evidence that immunization is one of the most effective public health interventions for precluding morbidity and mortality from vaccine-preventable diseases, vaccination rates remain suboptimal in multiple areas around the world owing to inappropriate information, false attitudes, apprehensions about adverse events, and population hesitancy. ${ }^{5,6}$

The involvement of healthcare practitioners is critical in shaping how patients or caregivers make vaccination decisions. Smith PJ et al. reported that parents who are influenced by healthcare practitioners are twice likely to believe that vaccination is safe for their children. ${ }^{7}$ Besides family physicians, non-traditional vaccine providers are proposed to augment immunization coverage. ${ }^{8,9}$ Pharmacists are frequently the first contact for patients seeking medical care as they are accessible and substantial healthcare providers. ${ }^{10,11}$ Hence, they can have multiple vital roles to educate, facilitate and immunize against vaccine-preventable diseases. ${ }^{12,13}$ While previous literature has reported vaccination-related knowledge, 
Sakr F, Akiki Z, Dabbous M, Salameh P, Akel M. The role of pharmacists in providing immunization to the general population: Are Lebanese pharmacists ready for this role? Pharmacy Practice 2021 Oct-Dec;19(4):2565.

https://doi.org/10.18549/PharmPract.2021.4.2565

attitudes and perceptions among various healthcare professionals, ${ }^{14-19}$ there is limited information about pharmacists, ${ }^{4,20,21}$ despite the fact that they have been involved in immunization tasks in several countries. ${ }^{22-24}$

A pharmacist-led immunization is globally broadening, though the pharmacist's role in providing immunization is still variable. In certain countries, pharmacists are primarily responsible for ensuring safe supply and dispensing of vaccines, in addition to advocating for immunization. On the other hand, they are legally empowered to organize vaccination activities and provide direct immunization services to the public in many other countries. In fact, Pharmacists have served as immunizers in many countries around the world, starting in 1996 in the United States (US) and 2007 in Canada. ${ }^{22,25}$ Legislation has enabled appropriately trained and licensed pharmacists in these countries to administer injectable medications and permitted them to immunize those who are 5 years of age and above. ${ }^{26,27}$

Lebanon is an upper-middle income country that is currently encountering a catastrophic socioeconomic and financial crisis that possibly ranks among the top 3 most severe global crisis episodes, and thus deteriorating the national societal and medical necessities. ${ }^{28,29}$ There is a scarcity of data around immunization and the role of the Lebanese healthcare providers in promoting vaccination. Most of the published non-COVID-19 literature focus mainly on the Human Papilloma Virus (HPV) vaccination. ${ }^{30,31}$ The Lebanese law of practicing the pharmacy profession allows pharmacists to exclusively sell vaccines in community, ambulatory and other practice settings, however, the corresponding legislation does not describe the scope of pharmacy practice in administering vaccination and other injectable medications. ${ }^{32}$ Therefore, the role of pharmacists as immunizers is still controversial in Lebanon and limited data are available around the expertise and practices of the Lebanese pharmacists in this public health task. This study aimed to determine predictors that are associated with vaccine administration by pharmacists in Lebanon, and to assess experiences and practices in providing immunization.

\section{METHODS}

\section{Study design and participants}

This paper is part of a national project that included pharmacists from all over Lebanon using a crosssectional study design. A snowball sampling technique was used to collect data through an electronic selfadministered questionnaire between March and June 2021. The web-link to the survey was also shared on the Order of Pharmacists of Lebanon (OPL) smart phone application with all registered pharmacists to gather a sample from different districts all over Lebanon. A cover letter with detailed information to explain the objective and context of the study was sent. The time to complete the questionnaire was around 20 minutes. All registered pharmacists in Lebanon practicing in community, hospital or other clinical settings were considered eligible for participation.

\section{Study instrument and outcomes}

The questionnaire used in this study was developed initially by the American Pharmacists Association, ${ }^{33}$ then adjusted and validated in another research. ${ }^{34}$ We received permission to adapt the latter version. Reliability testing was performed and showed a good internal consistency with our sample (Cronbach'salpha 0.717). ${ }^{35}$

The questionnaire included a total of 50 questions distributed over 5 parts. The first part included the sociodemographic characteristics relating to age, gender, practice settings, working status, highest level of education, years of experience, and the geographical area of practice. In the second part, self-experience with vaccination and completion of an immunization training program were assessed. The third part of the questionnaire determined services and barriers to provide immunization in the practice settings of the participants. The fourth part assessed immunization services provided by the pharmacist. A 5-point Likert scale ranging from "Never" to "Always" recognized different tasks completed by the pharmacist when providing immunization services including patient counseling, and managing vaccine related adverse and allergic reactions. The last part assessed perception of pharmacists around being recognized as immunizers.

\section{Ethical aspects}

The study protocol was approved by the Ethics and Research Committee of the School of Pharmacy at the Lebanese International University (2020RC-033-LIUSOP). Anonymity and confidentiality of all participants are warranted as the study was observational and personal identifiers were not traced during data collection and analysis. All participants agreed to participate before being able to fill the survey and informed consent was obtained.

\section{Sample size calculation}

CDC's Epi Info version 7.2.4. for population surveys was used to calculate the required sample size. The expected frequency that yielded the largest sample size for the major outcomes was used. Therefore, an overall minimum sample size of 137 pharmacists was required based on an expected frequency of $90 \%{ }^{34}$ to allow for adequate power of statistical analysis, and to produce a $95 \%$ confidence level and an acceptable margin of error of $5 \%$.

\section{Statistical analysis}

Data were converted from Google Form to Microsoft Excel, and then analyzed using IBM Statistical Package for Social Sciences (IBM SPSS) version 26.0. Sociodemographic characteristics 
Sakr F, Akiki Z, Dabbous M, Salameh P, Akel M. The role of pharmacists in providing immunization to the general population: Are Lebanese pharmacists ready for this role? Pharmacy Practice 2021 Oct-Dec;19(4):2565.

https://doi.org/10.18549/PharmPract.2021.4.2565

were evaluated by descriptive analysis. Categorical variables were expressed as frequencies and percentages, and were compared in the bivariate analyses using chi-square. All variables with $p$-value lower than 0.2 in the bivariate analysis were included in a multivariable analysis. A binomial logistic regression model using forward stepwise likelihood ratio method evaluated the sociodemographic characteristics and the pharmacists' attitudes and experiences as the independent predicting variables on administering vaccines as the dependent variable. Adjusted odds ratios (ORa) were used to report the results with a 95\% confidence interval. The level of significance was set at $p \leq 0.05$ and an acceptable margin of error $=5 \%$.

\section{RESULTS}

\section{Pharmacists' characteristics and experiences}

A total sample of 315 pharmacists was reached. The sample included $79.4 \%$ females, $74.9 \%$ between 20 to 29 years of age, and $49.5 \%$ hold PharmD degree as the highest level of education. The primary practice setting included $81.6 \%$ in a community pharmacy, $56.8 \%$ with full-time job, $50.8 \%$ being staff pharmacists, and $64.1 \%$ do not work in any other practice setting. With respect to the working experience, $41.0 \%$ had one to four years of experience, and $31.7 \%$ were practicing in Beirut. The complete characteristics and experiences of the participating pharmacists are reported in Table 1.

Bivariate analysis of pharmacists' characteristics, practices and experiences on administering vaccination

Greater than half of the pharmacists ( $N=186,59.0 \%)$ administer vaccines to patients. Having a PharmD degree $(P=0.04)$, practicing primarily in a community setting $(P<$ $0.0001)$, full-time employment $(P<0.0001)$, having one to nine years of practice experience $(P<0.0001)$, completion of an immunization training program $(P=0.003)$, planning to complete a future immunization training program $(\mathrm{P}=$ $0.034)$, and often to always educating the public about immunization $(P<0.0001)$ are significantly associated with administration of vaccines in pharmacy practice. There is also a significant association between the job title being $86.4 \%$ pharmacy owner, $72.5 \%$ pharmacy manager, $53.8 \%$ staff pharmacist, $25 \%$ clinical pharmacist (no dispensing), and $33.3 \%$ hospital pharmacist; and administering vaccination $(\mathrm{P}<0.0001)$. Table 2 documents the bivariate analysis of characteristics, practices and experiences of pharmacists on vaccine administration.

Multivariable analysis of pharmacist's characteristics, practices and experiences on administering vaccination

There is a significant association between completion of an immunization training program, primary practice setting, working status, years of experience, geographic area of practice, and educating the public about immunization;

\begin{tabular}{|c|c|}
\hline Characteristic & N (\%) \\
\hline \begin{tabular}{cl}
\multicolumn{2}{l}{ Age classes } \\
: & $20-29$ \\
: & $30-39$ \\
: & $40-49$ \\
& 250
\end{tabular} & $\begin{array}{l}236(74.9) \\
62(19.7) \\
9(2.9) \\
8(2.5)\end{array}$ \\
\hline $\begin{aligned} \text { Gender } & \\
\text { : } & \text { Male } \\
\text { - } & \text { Female }\end{aligned}$ & $\begin{array}{c}65(20.6) \\
250(79.4)\end{array}$ \\
\hline $\begin{aligned} & \text { Highest education level } \\
& \text { - } \\
& \text { : } \text { Machelor Degree (BPharm) } \\
& \text { - } \text { PharmD } \\
&\end{aligned}$ & $\begin{aligned} & 128(40.6) \\
& 23(7.3) \\
& 156(49.5) \\
& 8(2.5)\end{aligned}$ \\
\hline $\begin{array}{cl}\text { Primary practice setting } \\
\text { - } & \text { Community Pharmacy } \\
\text { - } & \text { Hospital Pharmacy } \\
\text { - } & \text { Pharmaceutical Company }\end{array}$ & $\begin{array}{l}257(81.6) \\
28(8.9) \\
26(8.3) \\
4(1.3)\end{array}$ \\
\hline $\begin{array}{l}\text { Working status } \\
\text { - } \quad \text { Full Time } \\
\text { Part Time }\end{array}$ & $\begin{array}{l}179(56.8) \\
136(43.2)\end{array}$ \\
\hline $\begin{aligned} & \text { Job title } \\
& \text { - } \text { Staff Pharmacist } \\
& \text { - } \text { Pharmacy Owner } \\
& \text { - } \text { Clinical Pharmanacist (no dispensing) } \\
& \text { - } \text { Hospital Pharmacist } \\
&\end{aligned}$ & $\begin{array}{l}160(50.8) \\
59(18.7) \\
51(16.2) \\
37(11.1) \\
9(2.9)\end{array}$ \\
\hline $\begin{array}{l}\text { Other practice setting } \\
\text { Academia } \\
\text { - } \quad \text { Hospital Pharmacy } \\
\text { I do not work in any other practice setting }\end{array}$ & $\begin{array}{c}86(27.3) \\
23(7.3) \\
4(1.3) \\
202(64.1)\end{array}$ \\
\hline $\begin{aligned} & \text { Years of experience } \\
& \text { - } \text { New graduate }(<1 \text { year) } \\
& \text { - } 1 \text { to } 4 \text { years } \\
& \text { - } 10 \text { to } 14 \text { years } \\
& \text { - } 15 \text { to } 19 \text { years } \\
& \text { - }>20 \text { years }\end{aligned}$ & $\begin{array}{c}103(32.7) \\
129(41.0) \\
44(14.0) \\
24(7.6) \\
5(1.6) \\
10(3.2)\end{array}$ \\
\hline $\begin{aligned} \text { Geographic area of practice } \\
\text { - } \text { Beirut } \\
\text { : } \text { Bekaa } \\
\text { - } \text { Nount Lebanon } \\
\text { South }\end{aligned}$ & $\begin{array}{l}100(31.7) \\
48(15.2) \\
76(24.1) \\
34(10.8) \\
57(18.1)\end{array}$ \\
\hline $\begin{array}{l}\text { Completion of immunization training program } \\
\text { - No } \\
\text { - Yes }\end{array}$ & $\begin{array}{c}239(75.9) \\
76(24.1)\end{array}$ \\
\hline $\begin{array}{l}\text { Plan to complete immunization training program in the future } \\
\text { No } \\
\text { Yes }\end{array}$ & $\begin{aligned} 23 & (9.1) \\
230 & (90.9)\end{aligned}$ \\
\hline $\begin{array}{c}\text { Do you educate the public about immunization? } \\
\text { Often - Always } \\
\text { - Sometimes } \\
\text { Rarely - Never }\end{array}$ & $\begin{array}{l}189(60.0) \\
75(23.8) \\
51(16.2)\end{array}$ \\
\hline
\end{tabular}


Sakr F, Akiki Z, Dabbous M, Salameh P, Akel M. The role of pharmacists in providing immunization to the general population: Are Lebanese pharmacists ready for this role? Pharmacy Practice 2021 Oct-Dec;19(4):2565.

https://doi.org/10.18549/PharmPract.2021.4.2565

\begin{tabular}{|c|c|c|c|}
\hline Characteristic/Variable & $\begin{array}{c}\text { Do not administer vaccines to } \\
\text { patients } \\
\mathrm{N}=129(41.0 \%) \\
\mathrm{N}(\%)\end{array}$ & $\begin{array}{c}\text { Administer vaccines to } \\
\text { patients } \\
\mathrm{N}=186(59.0 \%) \\
\mathrm{N}(\%)\end{array}$ & P-value \\
\hline $\begin{aligned} & \text { Age classes } \\
&: 20-29 \\
&: 30-39 \\
&: \geq 40\end{aligned}$ & $\begin{array}{l}94(39.8) \\
27(43.5) \\
8(47.1)\end{array}$ & $\begin{array}{l}142(60.2) \\
35(56.5) \\
9(52.9)\end{array}$ & 0.757 \\
\hline $\begin{aligned} \text { Gender } & \\
\text { - } & \text { Male } \\
\text { - } & \text { Female }\end{aligned}$ & $\begin{array}{c}21(32.3) \\
108(43.2)\end{array}$ & $\begin{array}{c}44(67.7) \\
142(56.8)\end{array}$ & 0.073 \\
\hline $\begin{array}{c}\text { Highest education level } \\
\text { - } \text { Bachelor Degree (BPharm } \\
\text { - } \text { Masters } \\
\text { - PharmD } \\
\end{array}$ & $\begin{array}{c}60(46.9) \\
9(39.1) \\
54(34.6) \\
6(75.0)\end{array}$ & $\begin{array}{c}68(53.1) \\
14(60.9) \\
102(65.4) \\
2(25.0)\end{array}$ & 0.040 \\
\hline $\begin{aligned} & \text { Primary practice setting } \\
& \text { - } \text { Community Pharmacy } \\
& \text { - } \text { Hospital Pharmacy } \\
& \text { - } \text { Pharmaceutical Company }\end{aligned}$ & $\begin{array}{l}86(33.5) \\
21(75.0) \\
20(76.9) \\
2(50.0)\end{array}$ & $\begin{array}{l}171(66.5) \\
7(25.0) \\
6(23.1) \\
2(50.0)\end{array}$ & $<0.0001$ \\
\hline $\begin{array}{l}\text { Working status } \\
\text {. } \quad \text { Full Time } \\
\text {. Part Time }\end{array}$ & $\begin{array}{l}55(30.7) \\
74(54.4)\end{array}$ & $\begin{array}{l}124(69.3) \\
62(45.6)\end{array}$ & $<0.0001$ \\
\hline $\begin{aligned} & \text { Job title } \\
& \text { - } \text { Staff Pharmacist } \\
& \text { - } \text { Pharmacy Ownery Manager } \\
& \text { - } \text { Clinical Pharmacist (no dispensing) } \\
& \text { - } \text { Hospital Pharmacist } \\
&\end{aligned}$ & $\begin{array}{l}74(46.3) \\
8(13.6) \\
14(27.5) \\
27(75.0) \\
6(66.7)\end{array}$ & $\begin{array}{l}86(53.8) \\
51(86.4) \\
37(72.5) \\
9(25.0) \\
3(33.3)\end{array}$ & $<0.0001$ \\
\hline $\begin{array}{l}\text { Other practice setting } \\
\text { - } \quad \text { Academunity Pharmacy } \\
\text { - Hospital Pharmacy } \\
\text { I do not work in any other practice } \\
\text { setting }\end{array}$ & $\begin{array}{l}32(37.2) \\
10(43.5) \\
2(50.0) \\
85(42.1)\end{array}$ & $\begin{array}{l}54(62.8) \\
13(56.5) \\
2(50.0) \\
117(57.9)\end{array}$ & 0.849 \\
\hline $\begin{aligned} & \text { Years of experience } \\
& \text { - } \text { New graduate }(<1 \text { year) } \\
& \text { : } 1 \text { to } 4 \text { years } \\
& \text { - } \geq 10 \text { to } 9 \text { years } \\
&\end{aligned}$ & $\begin{array}{l}61(59.2) \\
34(26.4) \\
13(29.5) \\
21(53.8)\end{array}$ & $\begin{array}{l}42(40.8) \\
95(73.6) \\
31(70.5) \\
18(46.2)\end{array}$ & $<0.0001$ \\
\hline $\begin{aligned} \text { Geographic area of practice } \\
\text { - } \text { Beirut } \\
\text { - } \text { Bekaa } \\
\text { - } \text { Nount Lebanon } \\
\text { - South }\end{aligned}$ & $\begin{array}{l}40(40.0) \\
24(50.0) \\
21(27.6) \\
17(50.0) \\
27(47.4)\end{array}$ & $\begin{array}{l}60(60.0) \\
24(50.0) \\
55(72.4) \\
17(50.0) \\
30(52.6)\end{array}$ & 0.053 \\
\hline $\begin{array}{l}\text { Completion of immunization training program } \\
\text { No } \\
\text { Yes }\end{array}$ & $\begin{array}{c}109(45.6) \\
20(26.3)\end{array}$ & $\begin{array}{c}130(54.4) \\
56(73.7)\end{array}$ & 0.003 \\
\hline $\begin{array}{l}\text { Plan to complete immunization training program } \\
\text { in the future } \\
\text { No } \\
\text { Yes }\end{array}$ & $\begin{array}{l}15(65.2) \\
97(42.2)\end{array}$ & $\begin{array}{c}8(34.8) \\
133(57.8)\end{array}$ & 0.034 \\
\hline $\begin{array}{c}\text { Educating the public about immunization } \\
\text { - Often - Always } \\
\text { - } \text { Sometimes } \\
\text { Rarely - Never }\end{array}$ & $\begin{array}{l}56(29.6) \\
41(54.7) \\
32(62.7)\end{array}$ & $\begin{array}{l}133(70.4) \\
34(45.3) \\
19(37.3)\end{array}$ & $<0.0001$ \\
\hline
\end{tabular}


Sakr F, Akiki Z, Dabbous M, Salameh P, Akel M. The role of pharmacists in providing immunization to the general population: Are Lebanese pharmacists ready for this role? Pharmacy Practice 2021 Oct-Dec;19(4):2565.

https://doi.org/10.18549/PharmPract.2021.4.2565

and vaccine administration. Pharmacists who completed an immunization training program had approximately twice the odds of administering vaccination (ORa = 2.085, [95\%Cl 1.006:4.322], $P=0.048)$. Similarly, fulltime pharmacists had approximately twice the odds of administering vaccines (ORa $=2.504,[95 \% \mathrm{Cl} 1.156: 5.426]$, $P=0.02$ ). Pharmacists who have one to four years of practice experience have higher odds compared to new graduates with less than one year of practice (ORa = 3.855, [95\% Cl 1.849:8.039], $\mathrm{P}<0.0001)$. Pharmacists who work in Beirut and Mount Lebanon also have higher odds of vaccine administration compared to those working in the South of Lebanon (ORa $=3.201,[95 \% \mathrm{Cl} 1.242: 8.249]$, $\mathrm{P}=0.016 ; \mathrm{ORa}=5.373,[95 \% \mathrm{Cl} 1.859: 15.530], \mathrm{P}=0.002$ respectively). In addition, pharmacists who often to always educate the public about immunization have higher odds compared to those who never educate about immunization (ORa $=3.012$, [95\% Cl 1.281:7.083], $\mathrm{P}=0.011$ ) (Table 3).

\section{DISCUSSION}

This study investigated vaccination-related activities and predictors of offering immunization services by pharmacists in Lebanon, in the absence of clear legislation that regulates the role of pharmacists in the national immunization program. Greater than half of our participants administer vaccination to the public. Our findings reveal significantly higher provision of vaccination among well-trained pharmacists who completed an immunization training program, full-time workers, those with more years of experience, those who practice in major regions of the country, and pharmacists who fulfill their role as educators and regularly counsel the public about immunization.

The completion of an immunization training program has a significant impact on higher frequencies of vaccine administration. Nevertheless, the overall number of certified pharmacists to provide immunization is apparently low in our sample compared to well developed countries. ${ }^{34}$ As the extent of pharmacy-based immunization authority is expanding, important numbers of pharmacists have been globally certified to administer vaccination. ${ }^{36,37}$ In the US, pharmacists are mandated to complete a recognized immunization training program and blood borne pathogens training in order to administer vaccination. They must also get certified in cardiac life supports, and obtain legal authority. ${ }^{38-40}$ All immunizing pharmacists should warrant a safe and appropriate administration of vaccines in their practice, as more than 20,000 vaccination errors were previously reported. ${ }^{36}$

Pharmacists with one to four years of practice experience were remarkably administering more vaccination compared to less experienced and senior pharmacists. It is not fully understood if these practitioners are more interested in expanding their area of practice, or if they consider nontraditional services in order to sustain their employment. This was reported in 2018 by Gerges S. et al. where pharmacists felt obliged to provide immunization in order to keep employment. ${ }^{21}$ Our results do not appear to be confounded by the young age of our sample, as the multivariable analysis have demonstrated a significant positive association of having one to four years of practice experience on administering vaccination compared to new graduates of younger age.

Full-time pharmacists were found to administer more vaccination compared to part-time employees. This can be explained together with another important finding of our study that pharmacists who regularly educate the public on immunization are found to provide more vaccination. In fact, patient education and motivation, vaccine facilitation, and vaccination are three roles of pharmacists identified by the American Pharmacists Association (APhA) regarding immunization. ${ }^{41}$ Full-time pharmacists appear to be greatly available for additional tasks within their practice, and allocate a greater time to educate the community about health-related concerns, thus allowing for a better contribution toward these roles. Other studies have shown that pharmacists are ready to

\begin{tabular}{|c|c|c|c|}
\hline & Adjusted OR & P-value & 95\% Confidence Interval \\
\hline $\begin{array}{l}\text { Completion of immunization training program } \\
\text { - Yes versus No }\end{array}$ & 2.085 & 0.048 & $1.006: 4.322$ \\
\hline $\begin{array}{l}\text { Working status } \\
\text { - Full-time versus part-time }\end{array}$ & 2.504 & 0.02 & $1.156: 5.426$ \\
\hline $\begin{array}{l}\text { Year of experience } \\
\text { - } 1 \text { to } 4 \text { years versus new graduate (<1 year) }\end{array}$ & 3.855 & $<0.0001$ & $1.849: 8.039$ \\
\hline $\begin{array}{l}\text { Geographic area of practice } \\
\text { - } \quad \text { Beirut versus South } \\
\text { - } \quad \text { Mount Lebanon versus South }\end{array}$ & $\begin{array}{l}3.201 \\
5.373\end{array}$ & $\begin{array}{l}0.016 \\
0.002\end{array}$ & $\begin{array}{c}1.242: 8.249 \\
1.859: 15.530\end{array}$ \\
\hline $\begin{array}{l}\text { Educating the public about immunization } \\
\text { - Often - Always versus Rarely - Never }\end{array}$ & 3.012 & 0.011 & $1.281: 7.083$ \\
\hline
\end{tabular}


Sakr F, Akiki Z, Dabbous M, Salameh P, Akel M. The role of pharmacists in providing immunization to the general population: Are Lebanese pharmacists ready for this role? Pharmacy Practice 2021 Oct-Dec;19(4):2565.

https://doi.org/10.18549/PharmPract.2021.4.2565

get involved in vaccination counseling and promotion, and that simple education to the community can enhance immunization rates. ${ }^{4,42}$ In addition, patients frequently consult healthcare practitioners for vaccination, and their counseling is perceived very reliable. ${ }^{43}$

This study found better vaccine administration by pharmacists in Beirut and Mount Lebanon. The reason for this could be because Beirut, the capital of Lebanon, and Mount Lebanon include the major pharmacies in the country with larger capacity to provide vaccination among additional services; or because the public perception in these regions are in favor of acquiring more immunization. In rural areas around the world, vaccination acceptability is reportedly low. This is justified by lack of knowledge and wrong perception about immunization by the public. ${ }^{44}$ This finding is also possible in Lebanon as the national data on COVID-19 immunization reflect lower acceptance and coverage in rural areas. ${ }^{45}$

This study has several strengths. It is the first study to investigate the role and practices of pharmacists to lead national immunization services all over Lebanon. The study utilized a validated questionnaire that is adapted with permission, and had a good reliability and internal consistency testing. The results can be used as a starting point to address the needs of Lebanese pharmacists for further education and vaccination training programs. In addition, this study reflects the perspective of young pharmacists who are still exploring new roles within their practice. The limitations of the study include a possible selection bias due to the virtual snowball sampling. This technique may have directed the sample towards a subgroup of the pharmacists' population leading to a homogenous group of participants that were mainly young pharmacists with fewer years of experience. Another selection bias that could not be excluded is related to the geographic area of practice, though pharmacists from all districts of Lebanon participated, thus this bias is minimized. Another limitation is related to the cross- sectional design of the study that only demonstrated the degree of association of practice predictors on providing immunization, though it does not reflect a causal relationship between the characteristics of pharmacists and expertise on one hand, and vaccine administration on the other hand. In addition, the electronically selfadministered questionnaire could have led to response bias as it may have excluded senior pharmacists who lack adequate digital literacy. Finally, the study included young pharmacists mainly and therefore the findings cannot be generalized for senior pharmacists.

\section{CONCLUSION}

The study highlights the need for additional immunization training programs to pharmacists to expand their ability and role as immunizers. It also provides intuition for policy makers to upgrade legislation relating to pharmacy continuing education and immunization training in order to enable pharmacists to have a greater role in direct vaccination. Future work will involve senior pharmacists and will explore the mediator role of practice challenges on pharmacist-led immunization.

\section{CONFLICTS OF INTEREST}

The authors have nothing to disclose.

\section{FUNDING}

This research did not receive any specific grant from funding agencies in the public, commercial, or not-forprofit sectors.

\section{ACKNOWLEDGEMENTS}

The authors would like to thank the Order of Pharmacists of Lebanon for sharing the survey with all registered pharmacists.

\section{References}

1. World Health Organization (WHO). Vaccines and immunization. Published 2021. Accessed May 27, 2021. https://www.who. int/westernpacific/health-topics/vaccines-and-immunization

2. Plotkin SL, Plotkin SA. A Short History of Vaccination. In: Plotkin S, Orenstein W, Offit P, Edwards KM, eds. Plotkin's Vaccines. 7th Edition. Elsevier; 2018:1-15.

3. Centers for Disease Control and Prevention (CDC). Impact of vaccines universally recommended for children--United States, 1990-1998. MMWR Morb Mortal Wkly Rep. 1999;48(12):243-248.

4. Valiquette JR, Bédard P. Community pharmacists' knowledge, beliefs and attitudes towards immunization in Quebec. Can J Public Health Rev Can SantePublique. 2015;106(3):e89-94. doi:10.17269/cjph.106.4880

5. Dubé E, Vivion M, MacDonald NE. Vaccine hesitancy, vaccine refusal and the anti-vaccine movement: influence, impact and implications. Expert Rev Vaccines. 2015;14(1):99-117. doi:10.1586/14760584.2015.964212

6. Napolitano F, D’Alessandro A, Angelillo IF. Investigating Italian parents' vaccine hesitancy: A cross-sectional survey. Hum Vaccines Immunother. 2018;14(7):1558-1565. doi:10.1080/21645515.2018.1463943

7. Smith PJ, Kennedy AM, Wooten K, et al. Association Between Health Care Providers' Influence on Parents Who Have Concerns About Vaccine Safety and Vaccination Coverage. Pediatrics. 2006;118(5):e1287-e1292. doi:10.1542/peds.2006-0923 
Sakr F, Akiki Z, Dabbous M, Salameh P, Akel M. The role of pharmacists in providing immunization to the general population: Are Lebanese pharmacists ready for this role? Pharmacy Practice 2021 Oct-Dec;19(4):2565.

https://doi.org/10.18549/PharmPract.2021.4.2565

8. Prosser LA, O’Brien MA, Molinari NA, et al. Non-Traditional Settings for Influenza Vaccination of Adults: Costs and Cost Effectiveness. PharmacoEconomics. 2008;26(2):163-178. doi:10.2165/00019053-200826020-00006

9. Singleton JA, Poel AJ, Lu P-J, et al. Where adults reported receiving influenza vaccination in the United States. Am J Infect Control. 2005;33(10):563-570. doi:10.1016/j.ajic.2005.03.016

10. Alhomoud F, Almahasnah R, Alhomoud FK. "You could lose when you misuse" - factors affecting over-the-counter sale of antibiotics in community pharmacies in Saudi Arabia: a qualitative study. BMC Health Serv Res. 2018;18(1):915. doi:10.1186/ s12913-018-3753-y

11. Kotwani A, Wattal C, Joshi PC, et al. Irrational use of antibiotics and role of the pharmacist: an insight from a qualitative study in New Delhi, India: Antibiotic dispensing practices of pharmacists in New Delhi. J Clin Pharm Ther. 2012;37(3):308-312. doi:10.1111/j.1365-2710.2011.01293.x

12. American Pharmacists Association. Guidelines for Pharmacy-based Immunization Advocacy and Administration. Published online 2019. Accessed May 27, 2021. https://www.pharmacist.com/sites/default/files/files/Guidelines_for_Pharmacy_ Based_IMZ_Advocacy_Approved_Jan_26_2019.pdf

13. Canadian Pharmacists Association. Influenza Immunization Guide for Pharmacists 2015. Published online 2015. Accessed May 27, 2021. https://www.pharmacists.ca/cpha-ca/assets/File/education-practice-resources/InfluenzaGuide_English_2015(1). pdf

14. Alshammari TM, Yusuff KB, Aziz MM, et al. Healthcare professionals' knowledge, attitude and acceptance of influenza vaccination in Saudi Arabia: a multicenter cross-sectional study. BMC Health Serv Res. 2019;19(1):229. doi:10.1186/s12913019-4054-9

15. Chhabra D, Mishra S, Gawande K, et al. Knowledge, attitude, and practice study on hepatitis B among medical and nursing undergraduate students of an apex healthcare institute at Uttarakhand foothills: A descriptive analysis. J Fam Med Prim Care. 2019;8(7):2354. doi:10.4103/jfmpc.jfmpc_331_19

16. Chotta NAS, Mgongo M, Uriyo JG, et al. Awareness and Factors Associated with Health Care Worker's Knowledge on Rubella Infection: A Study after the Introduction of Rubella Vaccine in Tanzania. Int J Environ Res Public Health. 2019;16(10):1676. doi:10.3390/ijerph16101676

17. Picchio CA, Carrasco MG, Sagué-Vilavella M, et al. Knowledge, attitudes and beliefs about vaccination in primary healthcare workers involved in the administration of systematic childhood vaccines, Barcelona, 2016/17. Eurosurveillance. 2019;24(6). doi:10.2807/1560-7917.ES.2019.24.6.1800117

18. Napolitano F, Navaro M, Vezzosi L, et al. Primary care pediatricians' attitudes and practice towards HPV vaccination: A nationwide survey in Italy. Spearman P, ed. PLOS ONE. 2018;13(3):e0194920. doi:10.1371/journal.pone.0194920

19. Anastasi D, Di Giuseppe G, Marinelli P, et al. Paediatricians knowledge, attitudes, and practices regarding immunizations for infants in Italy. BMC Public Health. 2009;9(1):463. doi:10.1186/1471-2458-9-463

20. Edwards N, Gorman Corsten E, Kiberd M, et al. Pharmacists as immunizers: a survey of community pharmacists' willingness to administer adult immunizations. Int J Clin Pharm. 2015;37(2):292-295. doi:10.1007/s11096-015-0073-8

21. Gerges S, Peter E, Bowles SK, et al. Pharmacists as vaccinators: An analysis of their experiences and perceptions of their new role. Hum Vaccines Immunother. 2018;14(2):471-477. doi:10.1080/21645515.2017.1403695

22. Hogue MD, Grabenstein JD, Foster SL, et al. Pharmacist Involvement with Immunizations: A Decade of Professional Advancement. J Am Pharm Assoc. 2006;46(2):168-182. doi:10.1331/154434506776180621

23. Burson RC, Buttenheim AM, Armstrong A, et al. Community pharmacies as sites of adult vaccination: A systematic review. Hum Vaccines Immunother. 2016;12(12):3146-3159. doi:10.1080/21645515.2016.1215393

24. Isenor JE, Edwards NT, Alia TA, et al. Impact of pharmacists as immunizers on vaccination rates: A systematic review and metaanalysis. Vaccine. 2016;34(47):5708-5723. doi:10.1016/j.vaccine.2016.08.085

25. Alberta College of Pharmacists. Alberta Influenza Immunization Program Resource Guide for Pharmacists. Published online 2012. Accessed May 27, 2021. https://abpharmacy.ca/sites/default/files/InfluenzalmmunizationResourceDoc.pdf?redirect

26. New Brunswick Pharmacists' Association. Flu shots at Pharmacies Gaining in popularity. Published 2014. Accessed May 27, 2021. https://nbpharma.ca/news/9/page-4

27. Pharmacists and Publicly Funded Vaccines in BC. General Information. Published 2021. Accessed May 27, 2021 . https://www2. gov.bc.ca/assets/gov/health/health-drug-coverage/pharmacare/vaccine-guide.pdf

28. The World Bank. Lebanon | Data. Published 2021. Accessed June 5, 2021. https://data.worldbank.org/country/LB

29. World Bank Group: Middle East and North Africa Region. Lebanon Economic Monitor, Spring 2021: Lebanon Sinking (to the Top 3). World Bank. Published 2021. Accessed June 5, 2021. https://www.worldbank.org/en/country/lebanon/publication/ lebanon-economic-monitor-spring-2021-lebanon-sinking-to-the-top-3

30. Abou El-Ola MJ, Rajab MA, Abdallah DI, et al. Low rate of human papillomavirus vaccination among schoolgirls in Lebanon: barriers to vaccination with a focus on mothers' knowledge about available vaccines. Ther Clin Risk Manag. 2018;14:617-626. doi:10.2147/TCRM.S152737 
Sakr F, Akiki Z, Dabbous M, Salameh P, Akel M. The role of pharmacists in providing immunization to the general population: Are Lebanese pharmacists ready for this role? Pharmacy Practice 2021 Oct-Dec;19(4):2565.

https://doi.org/10.18549/PharmPract.2021.4.2565

31. Abi Jaoude J, Khair D, Dagher H, et al. Factors associated with Human Papilloma Virus (HPV) vaccine recommendation by physicians in Lebanon, a cross-sectional study. Vaccine. 2018;36(49):7562-7567. doi:10.1016/j.vaccine.2018.10.065

32. Lebanese Parliament. The Law of Practicing the Pharmacy Profession in Lebanon. Order of Pharmacists of Lebanon. Published 1994. Accessed May 26, 2021. https://opl.org.lb/pdf/regulations/367.pdf

33. American Pharmacists Association. Annual Pharmacy Based Influenza and Adult Immunization Survey 2013. American Pharmacists Association; 2013:1-5. Accessed February 20, 2021. https://www.pharmacist.com/sites/default/files/files/ Annual\%20Immunization\%20Survey\%20Report.pdf

34. Isenor JE, Slayter KL, Halperin DM, et al. Pharmacists' immunization experiences, beliefs, and attitudes in New Brunswick, Canada. Pharm Pract. 2018;16(4):1310. doi:10.18549/PharmPract.2018.04.1310

35. Tavakol M, Dennick R. Making sense of Cronbach's alpha. Int J Med Educ. 2011;2:53-55. doi:10.5116/ijme.4dfb.8dfd

36. Bazzell B, Kelling S, Diez H, et al. Identifying Opportunities for Improvement in Safety and Efficacy of Community Pharmacy Immunization Programs. J Pharm Pract. 2019;32(4):428-433. doi:10.1177/0897190018761410

37. Schmit CD, Penn MS. Expanding state laws and a growing role for pharmacists in vaccination services. J Am Pharm Assoc JAPhA. 2017;57(6):661-669. doi:10.1016/j.japh.2017.07.001

38. ASHP. ASHP guidelines on the pharmacist's role in immunization. Am J Health-Syst Pharm AJHP Off J Am Soc Health-Syst Pharm. 2003;60(13):1371-1377. doi:10.1093/ajhp/60.13.1371

39. United States Department of Labor. Frequently Asked Questions - Needlesticks. Published 2021. Accessed June $21,2021$. https://www.osha.gov/needlesticks/needlefaq.html

40. United States Department of Labor. Bloodborne Pathogens - Overview | Occupational Safety and Health Administration. Published 2021. Accessed June 21, 2021. https://www.osha.gov/bloodborne-pathogens

41. Skelton JB, American Pharmacists Association, Academy of Managed Care Pharmacy. Pharmacist-provided immunization compensation and recognition: white paper summarizing APhA/AMCP stakeholder meeting. J Am Pharm Assoc JAPhA. 2011;51(6):704-712. doi:10.1331/JAPhA.2011.11544

42. Usami T, Hashiguchi M, Kouhara T, et al. Impact of community pharmacists advocating immunization on influenza vaccination rates among the elderly. YakugakuZasshi. 2009;129(9):1063-1068. doi:10.1248/yakushi.129.1063

43. Freed GL, Clark SJ, Butchart AT, et al. Sources and perceived credibility of vaccine-safety information for parents. Pediatrics. 2011;127 Suppl 1:S107-112. doi:10.1542/peds.2010-1722P

44. Qin S, Fu J-X, Chen M-Z, et al. Acceptability of vaccination against human papillomavirus among women aged 20 to 45 in rural Hunan Province, China: A cross-sectional study. Vaccine. 2020;38(30):4732-4739. doi:10.1016/j.vaccine.2020.05.017

45. Lebanese Ministry of Public Health. Today Vaccination on IMPACT. Published 2021. Accessed June 21, 2021. https://www. moph.gov.lb/maps/covid19.php 